\title{
Changes in Physicochemical, Microbiological, and Sensory Properties of Sun-Dried Mystus vittatus During Storage at Ambient Temperature
}

\author{
Bhaskar Chandra Majumdar ${ }^{1}$ (D), Faria Afrin ${ }^{1}$ (D), Md. Golam Rasul ${ }^{1}$ (D), \\ Dinesh Chandra Shaha 2 (D) and A.K.M. Azad Shah 1,* (D) \\ 1 Department of Fisheries Technology, Bangabandhu Sheikh Mujibur Rahman Agricultural University, \\ Gazipur-1706, Bangladesh; bhaskar.bsmrau@gmail.com (B.C.M.); faria3019@gmail.com (F.A.); \\ rasul@bsmrau.edu.bd (M.G.R.) \\ 2 Department of Fisheries Management, Bangabandhu Sheikh Mujibur Rahman Agricultural University, \\ Gazipur-1706, Bangladesh; dinesh@bsmrau.edu.bd \\ * Correspondence: azad@bsmrau.edu.bd; Tel.: +880-29205331
}

Received: 12 July 2018; Accepted: 14 August 2018; Published: 20 August 2018

\begin{abstract}
The objective of this study was to investigate the changes in physicochemical, microbiological, and sensory properties of sun-dried Mystus vittatus during storage at ambient temperature. The fish was dried under sun exposure on bamboo mats for 5-6 days until the moisture content reduced to approximately $10-15 \%$. The dried fish was then packed into airtight polyethylene bags and stored at ambient temperature $\left(24\right.$ to $\left.29^{\circ} \mathrm{C}\right)$ for 90 days. The physical and sensory properties revealed that the dried fish was acceptable for human consumption for up to 60 days. The $\mathrm{pH}$ value slightly decreased from 6.42 to 5.95 during the storage period. The moisture content increased significantly $(p<0.05)$, while no significant difference was observed for the protein, lipid, and ash contents (on a dry matter basis) with the increase in the storage time. The peroxide value, acid value, and conjugated dienes of the lipids increased significantly during the storage period. The microbial load also increased with the increase in the storage period. The results of this study suggest that the product was slightly oxidized during the storage period and could be stored for up to two months.
\end{abstract}

Keywords: chemical composition; lipid oxidation; Mystus vittatus; sensory properties; storage time

\section{Introduction}

Dried fish is a very common food item among the people of Bangladesh, India, Taiwan, China, Korea, and Japan. It has a high market demand for its desirable taste and flavor. Dried fish products are easily storable, transportable, and marketable; thus, they can be found in the market throughout the year. In addition, there is no need to use any preservatives for the storage of dried fish products for longer periods. As traditional sun-drying is a low-cost preservation technique, therefore, a huge amount of freshwater and marine fish is usually preserved by processors in Bangladesh. It has been reported that the dried fish contains comparatively higher amounts of dietary protein, and to meet up the huge consumer demand, approximately $15 \%$ of fish is dried in Bangladesh [1]. Most important nutritional components that are indispensable for human health are also found in dried fish $[2,3]$. Moreover, the country earns a huge amount of foreign currency by exporting dried fish [4].

Nowadays, people are more aware about their health and the nutritional value of food when they buy products for their consumption $[5,6]$. It has been reported that traditionally produced dried fish found in local markets is unsafe for human health on the basis of its physicochemical and organoleptic qualities $[7,8]$. During the drying and storage of sun-dried fish, fly and insect infestations 
that may reduce the consumer acceptability and quality of the final product are the major concerns [9]. In addition, dried fish products stored for longer periods usually develop a brown or yellow-brownish color, which suggests deterioration of the product quality [10]. It has been reported that the dried fish products found in Bangladesh are highly oxidized [11], which may have some adverse effects on human health.

Mystus vittatus (also known as tengra in Bengali) is an important fish species found in Bangladesh. The dried fish produced from tengra is widely accepted in Bangladesh for its characteristic taste, flavor, and low price. Moreover, the product contains comparatively higher amounts of lipids compared to others [12], which makes it more susceptible to oxidation. However, little is known about the quality changes of $M$. vittatus during storage at ambient temperature. Therefore, the present study aimed to evaluate the changes in physicochemical, microbiological, and sensory characteristics of sun-dried M. vittatus during storage at ambient temperature.

\section{Results}

\subsection{Changes in Physical and Sensory Characteristics of Mystus vittatus}

Changes in the physical and sensory characteristics of dried M. vittatus are presented in Table 1. The color, odor, texture, and insect infestation of samples of $M$. vittatus showed that they were of excellent quality for a storage period of up to 30 days. Then the product turned slightly black or yellow in color after a storage period of up to 90 days. The dry-fish odor, firmness, and elasticity of the texture were lost after a storage period of up to 60 days. However, the slightly rancid dry-fish odor decreased over the 90 days of storage. No insect infestation or broken pieces were seen in the dried fish during the storage period.

Table 1. Changes in sensory scores during storage of Mystus vittatus ${ }^{1}$.

\begin{tabular}{cccccc}
\hline Storage Time (days) & Color & Odor & Texture & Insect Infestation & Overall Acceptability \\
\hline 0 & $1.80 \pm 0.40^{\mathrm{a}}$ & $1.33 \pm 0.22^{\mathrm{a}}$ & $1.63 \pm 0.25^{\mathrm{a}}$ & $1.00 \pm 0.00^{\mathrm{a}}$ & $5.76 \pm 0.35^{\mathrm{a}}$ \\
30 & $3.60 \pm 1.77^{\mathrm{a}}$ & $1.58 \pm 0.65^{\mathrm{a}}$ & $1.90 \pm 0.18^{\mathrm{a}}$ & $1.00 \pm 0.00^{\mathrm{a}}$ & $8.08 \pm 1.12^{\mathrm{a}}$ \\
60 & $4.29 \pm 0.19^{\mathrm{b}}$ & $3.05 \pm 1.54^{\mathrm{a}}$ & $3.10 \pm 1.47^{\mathrm{a}}$ & $1.13 \pm 0.25^{\mathrm{a}}$ & $11.57 \pm 1.31^{\mathrm{b}}$ \\
90 & $4.89 \pm 0.06^{\mathrm{b}}$ & $6.29 \pm 0.17^{\mathrm{b}}$ & $5.23 \pm 0.34^{\mathrm{b}}$ & $1.65 \pm 0.31^{\mathrm{b}}$ & $18.06 \pm 2.00^{\mathrm{c}}$ \\
\hline
\end{tabular}

${ }^{1}$ Each value is expressed as a mean (1-10 scoring) \pm standard deviation (SD) $(n=7)$. Means with different superscripts within a column are significantly different $(p<0.05)$.

\subsection{Changes in Water Reconstitution of Dried Fish}

Water reconstitutions of $M$. vittatus are presented in Figure 1 . The results show that 0 -day sun-dried fish was shown to hold significantly $(p<0.05)$ the highest moisture content $(49.52 \%)$ after $60 \mathrm{~min}$ at room temperature, whereas no significant $(p>0.05)$ difference was observed in the dried fish stored for 30, 60, or 90 days; the dried fish samples were shown to have $43.78 \%, 41.21 \%$, and $39.25 \%$ moisture contents, respectively. In contrast, when the water temperature was increased to $40{ }^{\circ} \mathrm{C}$, the dried fish were rehydrated and the moisture contents significantly increased to $58.48 \%, 51.45 \%$, $50.76 \%$, and $47.64 \%$ for $0,30,60$, and 90 days, respectively, after $60 \mathrm{~min}$. Similar trends were also observed when the temperature was increased to $60^{\circ} \mathrm{C}$ for $60 \mathrm{~min}$ (Figure 1). However, no significant $(p>0.05)$ difference was observed in the water holding capacity at $60^{\circ} \mathrm{C}$ for $60 \mathrm{~min}$ when the samples were stored for 60 or 90 days.

\subsection{Changes in $p H$ Value of Dried Fish}

The $\mathrm{pH}$ value of dried $M$. vittatus significantly $(p<0.05)$ decreased from 6.42 to 6.06 within 30 days and then decreased slightly to 5.95 in the 90 days of storage (Figure 2). However, no significant difference was observed in the $\mathrm{pH}$ value during the storage period of 30 to 90 days. 

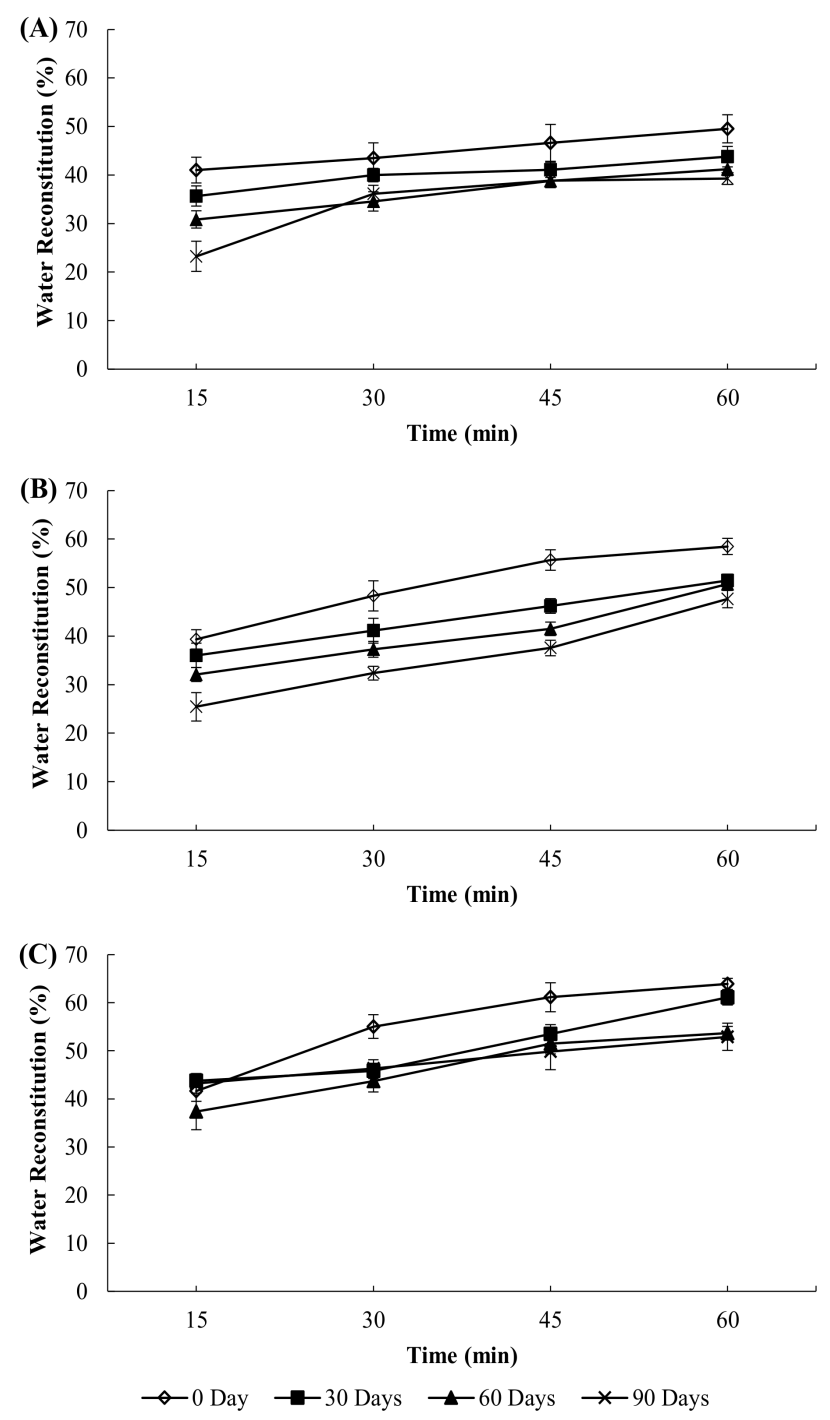

Figure 1. Water reconstitution of sun-dried M. vittatus at (A) room temperature, (B) $40^{\circ} \mathrm{C}$, and (C) $60^{\circ} \mathrm{C}$ during the storage period. The error bars represent means \pm SD of triplicates.

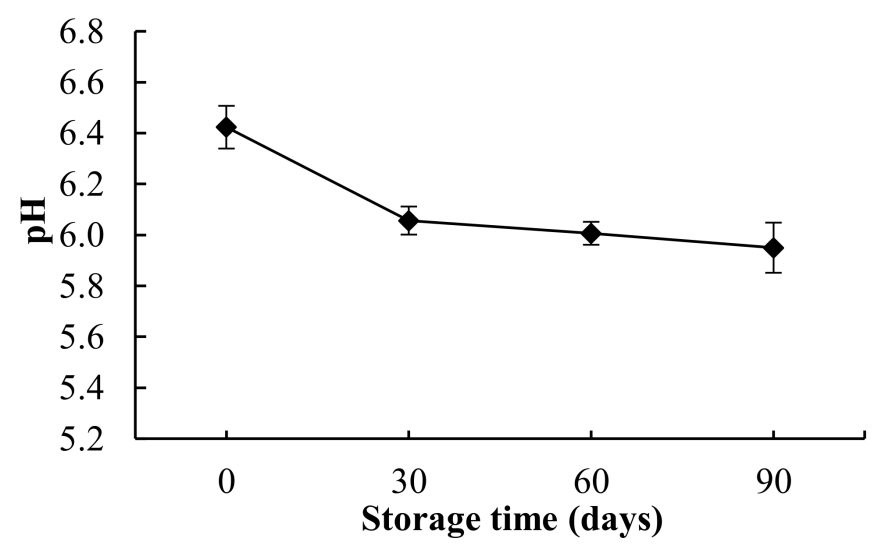

Figure 2. Changes in $\mathrm{pH}$ value of dried $M$. vittatus during storage. The error bars represent means \pm SD of triplicates. 


\subsection{Changes in Proximate Composition of Mystus vittatus}

Changes in the proximate composition of dried M. vittatus during storage are shown in Table 2. The moisture contents of $M$. vittatus ranged from $12.44 \%$ to $18.60 \%$. The highest moisture content $(18.60 \%)$ was observed in the dried fish stored for 90 days. The moisture content of the dried fish increased significantly $(p<0.05)$ with the increase in the storage period. The crude protein content of $M$. vittatus varied between $69.08 \%$ and $70.03 \%$ on a dry matter basis during the storage period. The highest crude protein content was observed for fish with the 0-day storage period. The crude lipid content of $M$. vittatus increased from $13.31 \%$ to $13.71 \%$ after 30 days of storage, while it decreased slightly to $12.42 \%$ after 90 days of storage on a dry matter basis. The ash content of $M$. vittatus varied between $16.61 \%$ and $17.08 \%$, and no significant difference was observed during the storage period.

Table 2. Changes in proximate composition (\% fresh matter basis) of dried M. vittatus during storage ${ }^{1}$.

\begin{tabular}{ccccc}
\hline Storage Time (days) & Moisture & Crude Protein Content & Lipid Content & Ash Content \\
\hline \multirow{2}{*}{0} & $12.44 \pm 0.29^{\mathrm{a}}$ & $61.32 \pm 1.15^{\mathrm{a}}$ & $11.65 \pm 0.79^{\mathrm{a}}$ & $14.54 \pm 0.45^{\mathrm{a}}$ \\
& & $\left(70.03 \pm 1.31^{\mathrm{e}}\right)^{*}$ & $\left(13.31 \pm 0.91^{\mathrm{e}}\right)$ & $\left(16.61 \pm 0.51^{\mathrm{e}}\right)$ \\
& & $59.48 \pm 1.06^{\mathrm{ab}}$ & $11.74 \pm 0.54^{\mathrm{a}}$ & $14.27 \pm 0.20^{\mathrm{ab}}$ \\
& $14.35 \pm 0.62^{\mathrm{b}}$ & $\left(69.45 \pm 1.24^{\mathrm{e}}\right)$ & $\left(13.71 \pm 0.63^{\mathrm{e}}\right)$ & $\left(16.66 \pm 0.23^{\mathrm{e}}\right)$ \\
& & $58.22 \pm 0.50^{\mathrm{bc}}$ & $11.11 \pm 0.44^{\mathrm{ab}}$ & $14.08 \pm 0.20^{\mathrm{ab}}$ \\
& & $\left(69.08 \pm 0.61^{\mathrm{e}}\right)$ & $\left(13.18 \pm 0.52^{\mathrm{e}}\right)$ & $\left(16.71 \pm 0.23^{\mathrm{e}}\right)$ \\
& $15.73 \pm 0.36^{\mathrm{c}}$ & $56.88 \pm 1.67^{\mathrm{c}}$ & $10.11 \pm 0.60^{\mathrm{b}}$ & $13.90 \pm 0.17^{\mathrm{b}}$ \\
& & $\left(69.88 \pm 2.05^{\mathrm{e}}\right)$ & $\left(12.42 \pm 0.73^{\mathrm{e}}\right)$ & $\left(17.08 \pm 0.21^{\mathrm{e}}\right)$ \\
\hline
\end{tabular}

${ }^{1}$ Each value is expressed as mean $\pm \mathrm{SD}(n=3)$. Means with different superscripts (a-d: fresh matter; e: dry matter) within a column are significantly different $(p<0.05) .{ }^{*}$ Figures in parentheses indicate values on dry matter basis.

\subsection{Oxidation of Lipid During Storage of Mystus vittatus}

Changes in the peroxide value (PV), acid value, and conjugated dienes (CD) of dried M. vittatus during storage are shown in Table 3. The PV of M. vittatus increased significantly from 12.08 to $25.35 \mathrm{meq} / \mathrm{kg}$ of lipids during the storage period. The acid value of $M$. vittatus ranged from 10.49 to $19.59 \mathrm{mg} \mathrm{KOH} / \mathrm{g}$ of lipids, increasing significantly $(p<0.05)$ to various extents during the storage period (Table 3). In this study, the CD of lipids ranged from 3.206 to 3.507, increasing significantly $(p<0.05)$ throughout the storage period. The maximum CD value was found for the 90 days of storage.

Table 3. Changes in peroxide value (PV), acid value, and conjugated dienes (CD) of dried M. vittatus during the storage period ${ }^{1}$.

\begin{tabular}{cccc}
\hline Storage Time (days) & $\begin{array}{c}\text { PV } \\
\text { (meq/kg of lipids) }\end{array}$ & $\begin{array}{c}\text { Acid Value } \\
\text { (mg KOH/g of lipids) }\end{array}$ & $\begin{array}{c}\text { CD } \\
\text { (OD 234 } \mathbf{~ n m ) ~}\end{array}$ \\
\hline 0 & $12.08 \pm 0.97^{\mathrm{a}}$ & $10.49 \pm 0.47^{\mathrm{a}}$ & $3.206 \pm 0.021^{\mathrm{a}}$ \\
30 & $13.95 \pm 0.88^{\mathrm{a}}$ & $11.81 \pm 0.45^{\mathrm{b}}$ & $3.325 \pm 0.045^{\mathrm{b}}$ \\
60 & $16.22 \pm 1.21^{\mathrm{b}}$ & $14.07 \pm 0.62^{\mathrm{c}}$ & $3.371 \pm 0.049^{\mathrm{b}}$ \\
90 & $25.35 \pm 1.04^{\mathrm{c}}$ & $19.59 \pm 0.72^{\mathrm{d}}$ & $3.507 \pm 0.046^{\mathrm{c}}$ \\
\hline
\end{tabular}

\footnotetext{
${ }^{1}$ Each value is expressed as mean $\pm \mathrm{SD}(n=3)$. Means with different superscripts within a column are significantly
} different $(p<0.05)$. OD, optical density.

\subsection{Quantitative Microbial Changes During Storage}

Changes in the microbial load of dried M. vittatus during storage are shown in Figure 3. The total bacterial loads of dried M. vittatus were $0.97,4.14,5.79$, and $8.88 \log C F U / g$ at $0,30,60$, and 90 days of storage, respectively. In this study, the bacterial load increased significantly $(p<0.05)$ with the increase in the storage period. 


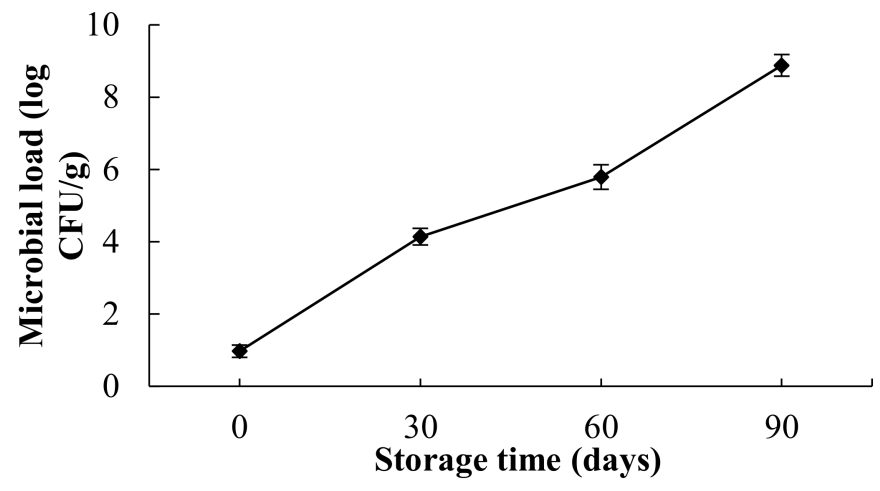

Figure 3. Changes in microbial load $(\log \mathrm{CFU} / \mathrm{g})$ of dried M. vittatus during storage. The error bars represent mean value $\pm \mathrm{SD}(n=6)$.

\section{Discussion}

Dried fish products are highly accepted by consumers because of their desirable taste, flavor, and numerous human health benefits. The overall acceptabilities were 5.76, 8.08, 11.57, and 18.06 in the dried fish stored for $0,30,60$, and 90 days, respectively. It has been suggested that a lower sensory score of dried fish indicates better quality of the product and vice versa. The characteristic color and odor of dried M. vittatus with up to 30 days of storage were excellent in quality. No insect infestation or broken pieces were observed throughout the storage period. A desirable texture remained within 30 days of storage. In the dried fish, a non-enzymatic browning reaction may have been attributable to the changes in color, which progressed continuously during the storage period $[13,14]$.

Increases in the reconstitution temperature and time have positive effects on the water holding capacity of dried fish. Moreover, the rehydration ability is proportionate to the physical properties of dried fish [8]. It has been reported that the internal structure of the dried fish muscle influences its the rehydration ability as a food product $[15,16]$. Sikorski et al. [17] found that the water uptake of dried fish is completed within 3 to $15 \mathrm{~min}$. Moreover, poor texture and a compact structure with few interfibrillar spaces are responsible for reducing the overall reconstitution ability of sun-dried fish $[10,18]$.

The $\mathrm{pH}$ value of fish muscle is an important indicator to determine the quality of the fish. In our study, the $\mathrm{pH}$ value decreased with the increase in the storage time, which may have been due to the generation of free fatty acids that were formed by lipid hydrolysis. The decreasing $\mathrm{pH}$ trend in the dried fish was more or less similar to that reported by Shah et al. [19]. They observed that the $\mathrm{pH}$ value decreased from 6.79 to 6.42 during the drying of herring fillets.

During the storage period, the crude protein content of $M$. vittatus varied between $69.08 \%$ and $70.03 \%$ on a dry matter basis. Bhuiyan [20] found that the protein content of dried Harpodon nehereus and Johnius dussumieri varied from $55.8 \%$ to $75.9 \%$. In another study, it was found that the crude protein of traditionally produced silver pomfret and Bombay duck ranged from $41.16 \%$ to $54.32 \%$ and from $50.66 \%$ to $54.58 \%$, respectively [21]. The authors also reported that solar-dried fish contained comparatively higher amounts of protein than the traditional sun-dried fish. In this study, the crude lipid content ranged from $12.42 \%$ to $13.71 \%$ on a dry matter basis. However, the lipid content decreased slightly to $12.42 \%$ in the sample dried for 90 days, which may have been the result of oxidative degradation of the fish lipids. Aro et al. [22] reported that the lipid content of pickled herring significantly $(p<0.05)$ decreased from $13.80 \%$ to $11.50 \%$ during a storage period of 12 months, and our results were more or less similar to this research finding. During the storage period, the moisture content increased while the crude protein, crude lipid, and ash contents decreased on a fresh matter basis, which may have been the result of the rehydration of the dried fish.

In this study, the rate of lipid oxidation was measured by determining the acid value, PV and $\mathrm{CD}$ of the dried fish. Generally, off-flavor and off-odor develop in dried fish when the product is 
stored for longer periods, which may be due to the oxidation of lipids finally affecting the quality of the products [23]. In our study, significantly the highest PV was observed for fish with 90 days of storage, and the value was higher than the acceptable limits (PV $\leq 20 \mathrm{meq} / \mathrm{kg}$ fish lipid) for human consumption [24]. However, a slightly oxidized product enhances the characteristic taste and flavor of dried herring fillets [25]. Shah et al. [19] reported that the PV (5.52-11.86 meq/ $\mathrm{kg})$ of lipids increased significantly during the drying of herring (Clupea pallasii) fillets. In our study, the acid value was measured to determine the rate of lipid hydrolysis in the dried fish. Generally, fish muscle lipids are hydrolyzed by the activity of enzymes, which releases free fatty acids [26]. In this study, the acid value varied between 10.49 and $19.59 \mathrm{mg} \mathrm{KOH} / \mathrm{g}$ of dried fish lipids. The increased acid value suggested that free fatty acids might have been released by partial hydrolysis of lipids during storage of the dried fish. In addition, such free fatty acids are further oxidized and produce low molecular compounds that develop the off-odor and taste of dried fish products [27]. A progressive formation of oxidized products can also be determined by measuring the CD of lipids. In our study, the number of $C D$ of the dried fish lipids increased significantly $(p<0.05)$ during the storage period. Generally, after per-oxidation of lipids, polyunsaturated fatty acids are converted to conjugated double bonds $(C=C-C=C)$ from non-conjugated double bonds $(C=C-C-C=C)$ [28]. As a result, the ultraviolet absorption at $234 \mathrm{~nm}$ is increased [29], which is an indicator of auto-oxidation in lipids [30]. The increase in the CD value may have been due to the excessive oxidation of lipids during storage of the product. A gradual increase in the $C D$ value was also observed in the dorsal muscle of Atlantic pomfret stored under chilled conditions for a prolonged period [31].

The microbiological load of dried M. vittatus varied between 0.97 and $8.88 \log \mathrm{CFU} / \mathrm{g}$, increasing with the increase in the storage period. The increment in the microbial load of the dried fish during storage may have been due to the product being stored at ambient temperature in addition to it reabsorbing atmospheric moisture, which is favorable for microbial growth. Moreover, spores of bacteria may not be destroyed at the time of drying because of an inappropriate or low drying temperature, and thus, the spores multiply during the storage period. A comparatively higher microbial load was observed in the fish with a 90-day storage period; however, no studies have been reported about the acceptable limit of the microbial load for dried fish. In the case of fresh fish, the acceptable limit for the microbial load is $7 \log$ CFU/g [32]. It has been reported that the total plate count of some freshwater dried fish ranged from $1.84 \times 10^{4}$ to $5.3 \times 10^{6} \mathrm{CFU} / \mathrm{g}$, which was comparatively lower than the microbial load observed in this study [33]. Reza et al. [34] also found that the total microbial load of some dried fish products varied from 3.27 to $4.49 \mathrm{log} \mathrm{CFU} / \mathrm{g}$.

\section{Materials and Methods}

\subsection{Collection of Fish Samples}

The experiment was conducted in the Department of Fisheries Technology at Bangabandhu Sheikh Mujibur Rahman Agricultural University, Gazipur, Bangladesh. Freshwater tengra (M. vittatus) (length of $6.67 \pm 0.74 \mathrm{~cm}$ and weight of $2.71 \pm 1.22 \mathrm{~g}$ ) were purchased from the local fish market and were transported to the laboratory of the Department of Fisheries Technology in an insulated box in ice $(1: 1)$.

\subsection{Sun-Drying Method for Fish}

For the traditional sun-drying method, the collected fish were dressed, washed, and spread on bamboo mats without any pre-treatment such as icing, salting, or so on. The fish was then dried under sun exposure for 5-6 days until the moisture content reduced to approximately $10-15 \%$. The dried fish was packed into airtight polythene bags and stored at room temperature ( 24 to $29^{\circ} \mathrm{C}$ ). During the storage period, the quality of the dried fish was investigated after every 30-day interval by determining whether the sensory, chemical, and microbial aspects were acceptable for human consumption. 


\subsection{Determination of Physical and Sensory Properties}

Physical and sensory properties, such as color, odor, texture, and insect infestation, of the traditionally sun-dried fish were assessed following the modified method described by Rasul et al. [35]. The samples were presented to the trained sensory panelists in separated sensory booths. The panel was composed of seven well-trained assessors (aged between 26 and 37 years) from the Laboratory of Fisheries Technology, Bangabandhu Sheikh Mujibur Rahman Agricultural University, Bangladesh. The panelists were asked to evaluate the test samples using a scale of 1-10, where 1-2.99 indicated excellent quality, 3-5.99 indicated average quality, 6-7.99 indicated poor quality, and 8-10 indicated highly unacceptable quality. Scoring was done on the basis of the color, odor, texture, and insect infestation of the dried fish.

\subsection{Determination of Water Reconstitution Behavior}

The water reconstitution behavior was investigated according to the method described by Hasan et al. [36]. Briefly, about 8-10 g of the samples was taken, weighed by an analytical balance, and then immersed into water at room temperature, at $40{ }^{\circ} \mathrm{C}$, and at $60^{\circ} \mathrm{C}$. The dried fish was soaked into water for $60 \mathrm{~min}$. Any loose muscle attached to the samples was removed before dipping into the water. The dried fish was taken out of the water at every 15 min interval, and the surface water was removed with blotting paper before the reweighing of each sample by the analytical balance. The percentage of water uptake in the rehydrated fish was calculated using the following formula:

$$
\text { Water reconstitution }=\frac{W_{r}-W_{i}}{W_{i}} \times 100,
$$

where $W_{i}$ represents the initial weight of the dry fish and $W_{r}$ represents the weight of the dry fish after water absorption.

\subsection{Determination of $p H$}

To determine the $\mathrm{pH}$ value, $10 \mathrm{~g}$ of the samples were homogenized with a 10-fold volume of distilled water, and the $\mathrm{pH}$ was measured directly using a $\mathrm{pH}$ meter (Beckman Instruments, Inc., Fullerton, CA, USA).

\subsection{Proximate Composition Analysis}

The compositions of the moisture, crude protein, crude lipid, and ash contents were analyzed in triplicate according to the standard procedure given by the Association of Official Analytical Chemists (AOAC) methods [37].

\subsection{Extraction of Lipids}

Total lipids were extracted from the dried fish with a solvent combination of chloroform/ methanol/distilled water according to the method of Bligh and Dyer [38] with slight modifications, making the final ratio 10:5:3 $(v / v / v)$. The extracted lipids were dissolved in chloroform and stored at $-20{ }^{\circ} \mathrm{C}$ until further analysis.

\subsection{Determination of Peroxide Value}

The PV was determined according to the AOAC method [37]. Samples $(0.5 \mathrm{~g})$ were mixed with $30 \mathrm{~mL}$ of a solution of glacial acetic acid and chloroform (ratio of 3:2) in a conical flask, and then $0.5 \mathrm{~mL}$ of saturated potassium iodide was added. The mixture was kept in the dark for about $10 \mathrm{~min}$, and then $30 \mathrm{~mL}$ of distilled water and $0.5 \mathrm{~mL}$ of freshly prepared $1 \%$ starch were added. After shaking, the samples were titrated with $0.01 \mathrm{~N}$ sodium thiosulfate. The PV was expressed in units of milliequivalent per kilogram of lipids. 


\subsection{Determination of Acid Value}

To measure the acid value, $0.5 \mathrm{~g}$ of total lipids was mixed with an ethanol and diethyl ether solution $(1: 1 v / v)$ and phenolphthalein was added. The mixture was then titrated with $0.01 \mathrm{~N}$ potassium hydroxide. The result was expressed in milligram $\mathrm{KOH}$ per gram of lipids [37].

\subsection{Determination of Conjugated Dienes}

Conjugated dienes were measured following the method of Frankel et al. [39]. Lipids (0.1 g) were dissolved in $5.0 \mathrm{~mL}$ of isooctane, and the absorbance was measured at $234 \mathrm{~nm}$ using a UV-1601 Spectrophotometer (Shimadzu, Kyoto, Japan).

\subsection{Determination of Microbial Load}

The microbial load of the dried fish was determined by the aerobic plate count method. Physiological saline $(0.85 \% \mathrm{NaCl})$ solution and plate count agar (Hi media, Mumbai, India) of commercial preparations were prepared in the laboratory as per the method given in Cowan and Steel's manual for the identification of medical bacteria [40].

\subsection{Statistical Analysis}

All measurements were carried out in triplicate, and the results expressed as means \pm standard deviations. Data were subjected to one-way analysis of variance followed by Duncan's multiple range test to identify differences amongst the means at $p<0.05$ using Statgraphics version 7.0 for Windows (StatPoint Inc., The Plains, VA, USA).

\section{Conclusions}

The results of this study demonstrate that the physical and sensory characteristics of the dried fish were of excellent quality for up to 30 days of storage; the product was also found to be acceptable for up to 60 days. Some changes in chemical composition occurred during the storage of the dried fish. The PV, acid value and CD of the lipids increased significantly over the storage time. The microbial load also revealed that the product was satisfactory for up to 60 days. It can be concluded from the results that the dried fish was slightly oxidized during the storage period and was safe for human consumption for up to 60 days.

Author Contributions: A.K.M.A.S. conceived and designed the study. B.C.M., F.A., and M.G.R. performed the experiments, and D.C.S. analyzed the data. A.K.M.A.S. contributed reagents/materials/analysis tools. B.C.M. led the writing of the manuscript with contributions from all authors.

Funding: This research was funded by the Research Management Committee (RMC) of BSMRAU, Gazipur and by the University Grant Commission (UGC), Bangladesh under Grant No. 2014-15/B(08).

Acknowledgments: The authors wish to thank DR. Mueena Jahan, Department of Microbiology and Public Health of BSMRAU, Gazipur for helping with the microbiological analysis.

Conflicts of Interest: The authors declare no conflict of interest.

\section{References}

1. Khan, M.A.A.; Khan, Y.S.A. Insects infestation and preventive measures in dry fish storage of Chittagong, Bangladesh. J. Biol. Sci. 2001, 1, 963-965.

2. Sutharshiny, S.; Sivashanthini, K. Proximate composition of three species of Scomberoides fish from Sri Lankan waters. Asia J. Clin. Nutr. 2011, 3, 103-111.

3. Koffi-Nevry, R.; Ouina, T.S.T.; Koussemon, M.; Brou, K. Chemical composition and lactic microflora of Adjuevan, a traditional Ivorian fermented fish condiment. Pak. J. Nutr. 2011, 10, 332-337. [CrossRef]

4. Azad, S.A. Yearbook of Fisheries Statistics of Bangladesh 2016-17; Department of Fisheries (DoF): Dhaka, Bangladesh, December 2017; Volume 34, pp. 1-129. 
5. Bhuiyan, M.N.H.; Bhuiyan, H.R.; Rahim, M.; Ahmed, K.; Haque, K.M.F.; Hassan, M.T.; Bhuiyan, M.N.I. Screening of organ chlorine insecticides (DDT and Heptachlor) in dry fish available in Bangladesh. Bangladesh J. Pharmacol. 2008, 3, 114-120. [CrossRef]

6. Hossain, M.M.; Heinonen, V.; Islam, K.M.Z. Consumption of foods and foodstuffs processed with hazardous chemicals: A case study of Bangladesh. Int. J. Consum. Stud. 2008, 32, 588-595. [CrossRef]

7. Saha, S.C. Studies on Production, Marketing and Nutritional Aspects of Traditional Dried Products of Bangladesh. Master's Thesis, Department of Fisheries Technology, Bangladesh Agricultural University, Mymensingh, Bangladesh, 1999.

8. Reza, M.S.; Bapary, M.A.J.; Azimuddin, K.M.; Nurullah, M.; Kamal, M. Studies on the traditional drying activities of commercially important marine fishes of Bangladesh. Pak. J. Biol. Sci. 2005, 8, 1303-1310.

9. Ahmed, M.; Bhuiyan, A.D.; Alam, A.M.S.; Huda, S.M.S. Radiation disinfestation studies on sun-dried fish. Indo-Pacific Fishery Commission. In Proceedings of the 18th Session, Manila, Phillippines, 8-17 March 1978; Food and Agriculture Organization of the United Nations (FAO): Rome, Italy, 1978; pp. 310-321.

10. Connell, J.J. Some aspects of the texture of dehydrated fish. J. Sci. Food. Agric. 1957, 8, 326-353. [CrossRef]

11. Majumdar, B.C.; Afrin, F.; Rasul, M.G.; Khan, M.; Shah, A.K.M.A. Comparative study of physico-chemical, microbiological and sensory aspects of some sun-dried fishes in Bangladesh. Braz. J. Biol. Sci. 2017, 4, 323-331. [CrossRef]

12. Hossain, M.A.; Afsana, K.; Shah, A.K.M.A. Nutritional value of some small indigenous fish species (SIS) of Bangladesh. Bangladesh J. Fish. Res. 1999, 3, 77-85.

13. Koizumi, C.; Kurobe, S.; Nonaka, J. On the browning of dried fish products. Bull. Jpn. Soc. Sci. Fish. 1959, 25, 368-372. [CrossRef]

14. Takiguchi, A. Lipid oxidation and brown discoloration in niboshi during storage at ambient and low temperatures. Nippon Suisan Gakkaishi 1992, 58, 489-494. [CrossRef]

15. Akintunde, T.Y. Effect of soaking water temperature and time on some rehydration characteristics and nutrient loss in dried bell pepper. Agric. Eng. Int. CIGR J. 2008, 10, 8-13.

16. Brennan, J.G.; Butters, J.R.; Cowell, N.D.; Lilly, A.E.V. Food Engineering Operations, 3rd ed.; Elsevier Applied Science: London, UK, 1990; pp. 123-130.

17. Sikorski, Z.E.; Gildberg, A.; Ruiter, A. Fish Products. In Fish and Fishery Products, Composition, Nutritive Properties and Stability; Ruiter, A., Ed.; CAB International: Wageningen, The Netherlands, 1995; p. 387.

18. Lahiry, N.L.; Sen, D.; Visweswariah, P. Effect of varying proportions of salt to fish on the quality of sun drying mackerel. Food Sci. 1961, 10, 139-143.

19. Shah, A.K.M.A.; Tokunaga, C.; Kurihara, H.; Takahashi, K. Changes in lipids and their contribution to the taste of migaki-nishin (dried herring fillet) during drying. Food Chem. 2009, 115, 1011-1118. [CrossRef]

20. Bhuiyan, M.R. Proximate biochemical analysis and spoilage patter of six marine fishes of the Bay of Bengal. Master's Thesis, Institute of Marine Science and Fisheries, University of Chittagong, Chittagong, Bangladesh, 1992.

21. Haque, E.; Kamruzzaman, M.; Islam, M.S.; Sarwar, T.; Rahman, S.S.; Karim, M.R. Assessment and comparison of quality of solar tunnel dried Bombay duck and Silver Pomfret with traditional sun-dried samples. Int. J. Nutr. Food Sci. 2013, 2, 187-195. [CrossRef]

22. Aro, T.L.; Larmo, P.S.; Backman, C.H.; Kallio, H.P.; Tahvonen, R.L. Fatty acids and fat-soluble vitamin in salted herring (Clupea harengus) products. J. Agric. Food Chem. 2005, 53, 1482-1488. [CrossRef] [PubMed]

23. Ramanathan, L.; Das, N.P. Studies on the control of lipid oxidation in ground fish by some polyphenolic natural products. J. Agric. Food Chem. 1992, 40, 17-21. [CrossRef]

24. Connell, J.J. Control of Fish Quality, 4th ed.; Wiley-Blackwell: Hoboken, NJ, USA, 1995; p. 256.

25. Shah, A.K.M.A.; Ishihara, T.; Ogasawara, M.; Kurihara, H.; Baba, N.; Takahashi, K. Mechanism involved in the formation of characteristic taste and flavor during the production of dried herring (Clupea pallasii) fillet. Food Sci. Technol. Res. 2010, 16, 201-208. [CrossRef]

26. Pacheco-Aguilar, R.; Lugo-Sánchez, M.E.; Robles-Burgueño, M.R. Postmortem biochemical and functional characteristic of Monterey sardine muscle stored at $0{ }^{\circ}$ C. J. Food Sci. 2000, 65, 40-47. [CrossRef]

27. Toyomizu, M.; Hanaoka, K.; Yamaguchi, K. Effect of release of free fatty acids by enzymatic hydrolysis of phospholipids on lipid oxidation during storage of fish muscle at $-5^{\circ}$ C. Bull. Jpn. Soc. Sci. Fish. 1981, 47, 605-610. [CrossRef] 
28. Gunstone, F.D.; Norris, F.A. Oxidation. In Lipid in Foods: Chemistry, Biochemistry and Technology; Gunstone, F.D., Norris, F.A., Eds.; Pergamon Press: New York, NY, USA, 1983; pp. 58-65.

29. Zuta, P.C.; Simpson, B.K.; Zhao, X.; Leclerc, L. The effect of $\alpha$-tocopherol on the oxidation of Mackerel oil. Food Chem. 2007, 100, 800-807. [CrossRef]

30. Weber, J.; Bochi, V.C.; Ribeiro, C.P.; Victorio, A.M.; Emanuelli, T. Effect of different cooking methods on the oxidation, proximate and fatty acid composition of silver catfish (Rhamdia quelen) fillets. Food Chem. 2008, 106, 140-146. [CrossRef]

31. Perez-Alonso, F.; Arias, C.; Aubourg, S.P. Lipid deterioration during chilled storage of Atlantic Pomfret (Brama brama). Eur. J. Lipid Sci. Technol. 2003, 105, 661-667. [CrossRef]

32. Ojagh, S.M.; Rezaei, M.; Razavi, S.H.; Hosseini, S.M.H. Effect of chitosan coatings enriched with cinnamon oil on the quality of refrigerated rainbow trout. Food Chem. 2010, 120, 193-198. [CrossRef]

33. Mansur, M.A.; Rahman, S.; Khan, M.N.A.; Reza, M.S.; Kamrunnahar; Uga, S. Study on the quality and safety aspect of three sun-dried fish. Afr. J. Agric. Res. 2013, 8, 5149-5155.

34. Reza, M.S.; Bapary, M.A.J.; Islam, M.N.; Kamal, M. Optimization of marine fish drying using solar tunnel dryer. J. Food Process. Preserv. 2009, 33, 47-59. [CrossRef]

35. Rasul, M.G.; Majumdar, B.C.; Afrin, F.; Bapary, M.A.J.; Shah, A.K.M.A. Biochemical, microbiological, and sensory properties of dried Silver carp (Hypophthalmichthys molitrix) influenced by various drying methods. Fishes 2018, 3, 25. [CrossRef]

36. Hasan, M.M.; Rasul, M.G.; Ferdausi, H.J.; Trina, B.D.; Sayeed, A.; Shah, A.K.M.A.; Bapary, M.A.J. Comparison of organoleptic and chemical characteristics of some traditional and improved dried fish products. Res. J. Anim. Vet. Fish. Sci. 2016, 4, 1-6.

37. Association of Official Analytical Chemists (AOAC). Official Methods of Analysis, 16th ed.; AOAC International: Arlington, VA, USA, 1995.

38. Bligh, E.G.; Dyer, W.J. A rapid method of total lipid extraction and purification. Can. J. Physiol. Pharmacol. 1959, 37, 911-917.

39. Frankel, E.N.; Huang, S.W.; Prior, E.; Aeschbach, R. Evaluation of antioxidant activity of rosemary extracts, carnosol and carnosic acid in bulk vegetable oils and fish oil and their emulsions. J. Agric. Food Chem. 1996, 72, 201-208. [CrossRef]

40. Barraw, G.L.; Feltham, R.K.A. Cown and Steel's Manual for the Identification of Medical Bacteria, 2nd ed.; Barrow, G.I., Feltham, R.K.A., Eds.; Cambridge University Press: Cambridge, UK, 1993; p. 331. 